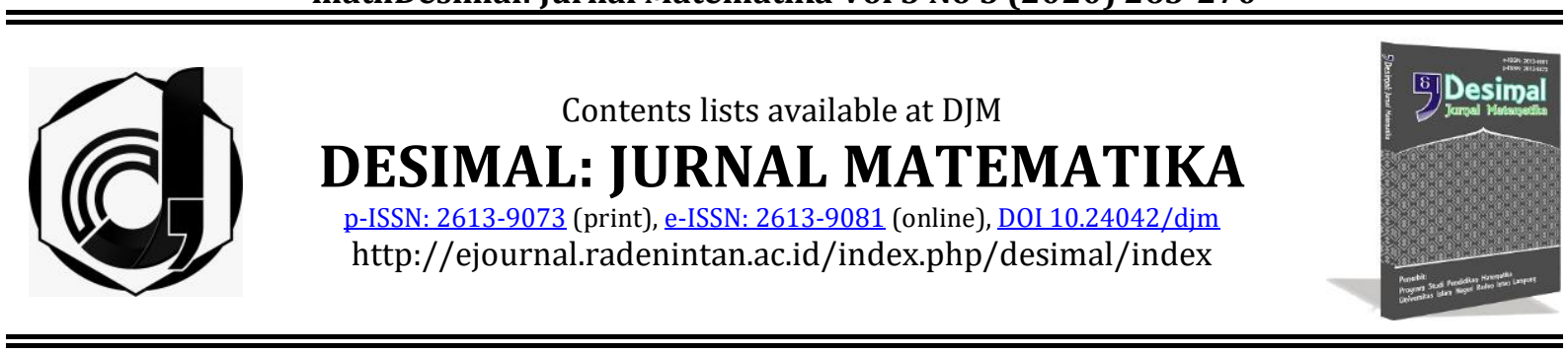

\title{
The Annual Premium of Life Insurance on The Joint-Life Status based on The 2011 Indonesian Mortality Table
}

\author{
Stacia Litha Suryani, Rudi Ruswandi, Ahmad Faisol ${ }^{*}$ \\ Universitas Lampung, Indonesia
}

\author{
ARTICLE INFO

\section{Article History} \\ Received : 28-06-2020 \\ Revised :09-09-2020 \\ Accepted :28-09-2020 \\ Published : 30-09-2020 \\ Keywords: continuous annual \\ premium; equivalence principle; \\ joint life insurance. \\ *Correspondence: E-mail: \\ ahmadfaisol@fmipa.unila.ac.id \\ Doi: \\ $\underline{10.24042 / \operatorname{djm} . v 3 i 3.6761}$
}

\begin{abstract}
Life insurance is insurance that protects against risks to someone's life. Joint Life Insurance is insurance where the life and death rules are a combination of two or more factors, such as husband-wife or parent-child, and if the first death occurs, then the premium payment process is stopped. The annual premium is the premium paid annually. In this study, the annual premium is calculated continuously with the equivalence principle based on the 2011 Indonesian Mortality Table. The calculation shows that the amount of annual premiums for 2 (two) and 3 (three) people is not much different. The factors that influence the annual premium amount are the duration insurance period, age at signing the policy, interest rates, life chances, force of mortality, and the number of benefits.
\end{abstract}

http://ejournal.radenintan.ac.id/index.php/desimal/index

\section{INTRODUCTION}

Everyone in their life has many risks of occurrence that maybe happen themselves that causes loss, such as accidents, damage, health, loss of life, and other unexpected events. According to (Sembiring, 1986), life is full of uncertainty. Everyone wants to have prospered; life prosperity will be disturbed if he is sick, disability, or died. Welfare guarantee can be obtained if he insures himself, guaranteeing that is given like compensation, so it can be concluded that insurance is a guarantee against the unexpected event that possibly happened to minimize risk. Insurance that guarantees a person's life is called life insurance.

Life insurance protects against the risk of someone's life who becomes an insured (Bhuana et al., 2015). Life insurance can be divided into two: life insurance for an individual is called single life insurance, while for more than one person is joint-life insurance (Futami, 1994). One type of combined life insurance is joint-life life insurance. Joint-life is a condition where the death rule of his life is a combination of two or more factors, such as husband and wife, parents, and children (Futami, 1994). An institution that provides various protection for its customer is called an insurance company. 
According to (Bowers et al., 1987), the insurance company will publish a contract that will promise to pay a specified amount, equal to or less from the loss during the policy period. Then it is started from the signing of the insurance policy. It means that it is started to switch the insured (customer) to the guarantor (company). Both sides in the insurance policy must obey the rule that each customer must pay a premium, while the company must provide rights to the suspended family (heirs) if a risk occurs, the right is called a benefit. The premium paid directly at the insurance contract time is agreed at once is called a single premium (Futami, 1993), but in reality, they are rarely used because they are too expensive to be paid at once. Premium payments can be made every year to facilitate customers. This payment is called the annual premium.

According to (Matvejevs \& Matvejevs, 2001), family insurance contracts have applied more than individual insurance, and family insurance is joint-life insurance. Therefore, they determine the annual premium for two people on discrete joint-life life insurance, and (Bhuana et al., 2015) also research to determine the annual premium for three people with the same type of insurance. The discrete premium calculation means that the insured's provided the benefit is carried out at the end of the year the insured dies, whereas for deaths that occur at the beginning of the year is very long to receive the provided benefit at the end of the year. Moreover, other research related to determining the annual premium by discrete calculations can be seen in (Ihsan et al., 2014) and (Bizaini et al., 2016).

Therefore, the author is motivated to determine the formulation of annual premiums with a type of joint-life insurance for two and three people continuously. The continuous premium calculation means that the benefit can be given directly when the insured dies but with the same amount of benefit if he dies within the specified policy, different from two previous journals with many benefits with premiums that have been paid. This study aims to determine the annual premium continuously from joint-life insurance for two people (husband and wife) and three people (husband, wife, and son).

\section{METHOD}

An insurance contract for two people consists of a married couple, with their ages, namely husband $(x)$ and wife $(y)$. Suppose both remain alive until the insurance contract expiration for $n$ years or reach $x+n$ and $y+n$ years. In that case, they get a benefit $Q$.

If one of the couples dies before the contract expires, for example, $x$ dies, then $y$, who remains alive until the end of the contract, starts in the $n$ year during a lifetime each year gets a benefit of $R y$, and vice-versa if $y$ died then $x$ gets a benefit of $R x$. If the couple both ( $x$ and $y$ ) dies before the contract expires, then the heir will receive a $J$ benefit as soon as they both die.

Furthermore, the insurance contract for three people consists of husband, wife, and son, with their age, namely husband $(x)$, wife $(y)$, and son $(z)$.

Suppose all three remain alive until the end of the contract for $n$ years or reach $x+$ $n, y+n$, and $n$ years. Then, they get benefits of $Q$. Furthermore, if one of three participants dies before the contract period ends, for example, $x$ died, $y$ and $z$ are still alive until the end of the contract, then $y$ and $z$ gets a benefit of Ryz. If $y$ dies, then $x$ and $z$ get a benefit of $R x z$, and so if $z$ dies, then $x$ and $y$ get a benefit of $R x y$. Meanwhile, if $x$ and $y$ die, while $z$ is still alive until the end of the contract, then starts in the $n$ year during a lifetime every year, gets a benefit of $R z$. If $x$ and $z$ die, then $y$ get a benefit of $R y$, and so if $y$ and $z$ die, then $x$ get a benefit of $R x$. If all their participant dies in the same year before 
the contract expires, then the heirs will receive a $J$ benefit as soon as three of them died.

In this research, the calculation of the formulation is based on the 2011 Indonesian mortality table. Then the formulation uses the symbols in the table. The chance of living a joint-life or the chance of survival for people aged $x_{1}, x_{2}$, $x_{3}, \ldots x_{m}$ will remain alive until they are $x$ $+n$ years old.

$$
{ }_{n} \mathrm{p}_{\mathrm{x}_{1}, \mathrm{x}_{2}, \mathrm{x}_{3}, \ldots \mathrm{x}_{\mathrm{m}}}={ }_{n} \mathrm{p}_{\mathrm{x}_{\mathrm{m}}} \mathrm{p}_{\mathrm{x}_{1}} \cdot{ }_{n} \mathrm{p}_{\mathrm{x}_{2} \cdot{ }_{n}} \mathrm{p}_{\mathrm{x}_{3}} \ldots
$$

For a joint-life, the chance of living for two people is denoted by ${ }_{n} p_{x y}$, and formulated as follows:

$$
{ }_{n} p_{x y}={ }_{n} p_{x} \cdot{ }_{n} p_{y}=\frac{l_{x+n ; y+n}}{l_{x y}}
$$

Whereas, for three people is denoted by ${ }_{n} p_{x y z}$, and formulated as follows:

$$
{ }_{n} p_{x y z}={ }_{n} p_{x} \cdot{ }_{n} p_{y \cdot n} p_{z}=\frac{l_{x+n ; y+n ; z+n}}{l_{x y z}}(3)
$$

The rate of death is the chance of person currently aged $x$ years will die sometime later or die between the ages of $x$ and $x+\Delta x$ with the condition of life at age $x$ is denoted by $\mu_{x(t)}$, and formulated as follows:

$\mu_{x(t)}=\frac{l_{x+t-1}-l_{x+t+1}}{2 l_{x+t}}$

Meanwhile, for two people, age $x$ and $y$ years and three people, age $x, y$, and $z$ years are denoted each $\mu_{x y(t)}$ and $\mu_{x y z(t)}$, and formulated as follows:

$\mu_{x y(t)}=\frac{l_{x+t-1 ; y+t-1}-l_{x+t+1 ; y+t+1}}{2 l_{x+t ; y+t}}$

$\mu_{x y z(t)}=$

$\frac{l_{x+t-1 ; y+t-1 ; z+t-1}-l_{x+t+1 ; y+t+1 ; z+t+1}}{2 l_{x+t ; y+t ; z+t}}$

A single premium is a premium that is paid directly when an insurance contract is agreed upon. Term life insurance is insurance with the benefit provided if the insured dies as long as the contract is not over. If he is still alive, then he does not get anything (Sembiring, 1986). Single life term joint-life insurance premium for two people age $x$ and $y$ years, with the contract for $n$ years, is denoted by $\bar{A}_{x y: \bar{n} \mid}^{1}$, and formulated as follows:

$\bar{A}_{x y: \overline{n \mid}}^{1}=\int_{0}^{n} v^{t}{ }_{t} p_{x y} \mu_{x y}(t) d_{t}$

Meanwhile, for three people age $x, y$, and $z$ years, with insurance contract for $n$ years is denoted by $\bar{A}_{x y z: \bar{n} \mid}^{1}$, and formulated as follows:

$\overline{\mathrm{A}}_{\mathrm{xyz}: \overline{\mathrm{n}} \mid}^{1}=\int_{0}^{\mathrm{n}} \mathrm{v}^{\mathrm{t}}{ }_{\mathrm{t}} \mathrm{p}_{\mathrm{xyz}} \mu_{\mathrm{xyz}}(\mathrm{t}) \mathrm{d}_{\mathrm{t}}$

Pure endowment life insurance is insurance with the benefit provided if the insured remains alive until the end of the insurance contract. If he dies, then he does not get anything (Sembiring, 1986). The single premium of pure joint-life endowment life insurance for two people age $x$ and $y$ years with a contract for $n$ years is denoted by $\bar{A}_{x y: n \mid} \frac{1}{n}$, and formulated as follows:

$\overline{\mathrm{A}}_{\mathrm{xy}: \mathrm{n} \mid}=\mathrm{v}^{\mathrm{n}} \cdot{ }_{\mathrm{n}} \mathrm{p}_{\mathrm{xy}}$

Meanwhile, for three people age $x, y$, and $z$ years with an insurance contract for $n$ years is denoted by $\bar{A}_{x y z: n \mid}$, and formulated as follows:

$$
\overline{\mathrm{A}}_{\mathrm{xyz}: \mathrm{n} \mid}=\mathrm{v}^{\mathrm{n}} \cdot{ }_{\mathrm{n}} \mathrm{p}_{\mathrm{xyz}}=\mathrm{v}^{\mathrm{n}} \cdot \frac{\mathrm{l}_{\mathrm{x}+\mathrm{n} ; \mathrm{y}+\mathrm{n} ; \mathrm{z}+\mathrm{n}}}{\mathrm{l}_{\mathrm{xyz}}}(10)
$$

An annuity is a series of payments for a certain period. A life annuity is a series of payments done during a person who is still alive, so this payment is associated with someone's life or death (Sembiring, 1986). Joint-life term annuity for two people age $x$ and $y$ for $n$ years is denoted by $\overline{\mathrm{a}}_{\mathrm{xy}}: \overline{\mathrm{n}} \mid$, formulated as follows:

$$
\bar{a}_{x y: \overline{n \mid}}=\int_{0}^{n}{ }_{t} p_{x y} v^{t} d t
$$

Meanwhile, for three people aged $x, y$, and $z$ years, with insurance contract for $n$ years are denoted by $\overline{\mathrm{a}}_{\mathrm{xyz}: \overline{\mathrm{n}} \mid}$, formulated as follows:

$$
\bar{a}_{x y z: \bar{n} \mid}=\int_{0}^{n}{ }_{t} p_{x y z} v^{t} d t
$$


An annuity paid after a while is called a deferred annuity (Futami, 1993). An annuity which is postponed $n$ years of joint-life for two people age $x$ and $y$ years is denoted by ${ }_{n \mid} \bar{a}_{x y}$, and formulated as follows:

$$
\begin{aligned}
{ }_{n \mid} \bar{a}_{x y} & =\int_{n}^{\infty}{ }_{t} p_{x y} v^{t} d t \\
& =\int_{n}^{\infty} \frac{l_{x+t ; y+t}}{l_{x y}} v^{t} d t
\end{aligned}
$$

Meanwhile, for three people age $x, y$, and $z$ years, with an insurance contract for $n$ years is denoted by $\mathrm{n} \mid \overline{\mathrm{a}}_{\mathrm{xyz}}$, and formulated as follows:

$$
\begin{aligned}
{ }_{n \mid} \bar{a}_{x y z} & =\int_{n}^{\infty}{ }_{t} p_{x y z} v^{t} d t \\
& =\int_{n}^{\infty} \frac{l_{x+t ; y+t ; z+t}}{l_{x y z}} v^{t} d t
\end{aligned}
$$

The premium amount sought in this study is determined by the principle of equivalence as follows:

$$
E(L)=0
$$

$L$ states that the amount of loss the guarantor is defined as a random variable from the cash benefit. According to (Sembiring, 1986), there is a healthy and fair guideline that "the value of future premiums = the value of future benefit" does not harm/benefit the insured or the guarantor. The translation of loss functions using the equivalence principle is as follows:

$$
\begin{aligned}
& E(L)=B E\left(V^{T}\right)-\bar{P} \cdot E\left(\bar{a}_{\bar{t} \mid}\right)=0 \\
& \bar{P} \cdot E\left(\bar{a}_{\bar{t} \mid}\right)=B \cdot E\left(V^{T}\right) \\
& \text { information: }
\end{aligned}
$$

B. $E\left(V^{T}\right)=$ Output (the insurer pays the value of the benefit).

$\bar{P} . E\left(\bar{a}_{\bar{t} \mid}\right)=$ Input (annual premium value).

$B=$ Amount of benefit (the company pays the amount of coverage).

$\bar{P}=$ Annual premium amount (the customer pays the amount of premium each year).

The formulation above can be concluded that the value of the benefit must be equal to the annual premium value. There is an equivalence principle that can be determined the amount of the annual premium of insurance. The procedure and data analysis technique should be emphasized in the literature review article.

\section{RESULTS AND DISCUSSION}

This chapter will determine the value of the annual premium and the value of the benefit paid by the guarantor because both of them are used to obtain the annual premium formulation of joint-life life insurance for two and three people based on the principle of equivalence with continuous calculation.

The annual premium for joint-life life insurance for two people is as follows:

1. Annual premium value (Input)

$$
\begin{aligned}
\bar{P} \cdot E\left(\bar{a}_{\overline{n \mid}}\right) & =\bar{P} \cdot \bar{a}_{x y: \bar{n} \mid} \\
& =\bar{P} \cdot \int_{0}^{n}{ }_{t} p_{x y} \cdot v^{t} d t .
\end{aligned}
$$

2. The value of the benefit is paid by the insurer (Output)

$$
\begin{aligned}
& \text { B. } E\left(V^{T}\right)=\left[\left(Q\left(\bar{A}_{x y}: \frac{1}{n \mid}\right)\right)+\left(R_{x \cdot n \mid} \bar{a}_{x . n} q_{y}\right)\right. \\
& \left.+\left(R_{y \cdot n \mid} \bar{a}_{y . n} q_{x}\right)+U \cdot\left(\bar{A}_{x y: \bar{n}}^{1}\right)\right] \text {. }
\end{aligned}
$$

3. By using the equivalence principle, the annual premium formulation is obtained

$$
\begin{aligned}
& \bar{P} \cdot \bar{a}_{x y: \bar{n} \mid}=\left(Q \cdot\left(\bar{A}_{x y: \frac{1}{n \mid}}\right)\right)+\left(R_{x \cdot n \mid} \bar{a}_{x . n} q_{y}\right) \\
& +\left(R_{y \cdot n \mid} \bar{a}_{y . n} q_{x}\right)+U \cdot\left(\bar{A}_{x y}^{1}: \bar{n} \mid\right) \cdot \bar{P}= \\
& \frac{\left(Q \cdot\left(\bar{A}_{x y}: \frac{1}{n \mid}\right)\right)+\left(R x \cdot n \mid \bar{a}_{x . n} q_{y}\right)}{\bar{a}_{x y: \bar{n} \mid}}+ \\
& \frac{\left(R y \cdot n \mid \bar{a}_{y . n} q_{x}\right)+\left(J \cdot\left(\bar{A}_{x y} \overline{1}_{\bar{n} \mid}\right)\right.}{\bar{a}_{x y: \bar{n} \mid}}
\end{aligned}
$$

Thus, the annual premium formula is denoted by $\bar{P}_{x y: n}$, and formulated as follows:

$$
\begin{aligned}
& \bar{P}_{x y: n}=\frac{\left(Q \cdot\left(\bar{A}_{x y}: \frac{1}{n \mid}\right)\right)+(R x \cdot n \mid}{\left.\bar{a}_{x . n} q_{y}\right)} \\
& \left.+\frac{\left(R y \cdot n \mid \overline{a_{y} \cdot n}\right.}{\bar{a}_{x y: \bar{n} \mid}} q_{x}\right)+\left(J \cdot\left(\bar{A}_{x y} \frac{1}{\bar{n}} \overline{n \mid}\right)\right.
\end{aligned}
$$


Meanwhile, for the annual premium formulation of joint-life insurance for three people as follows:

1. Annual premium value (Input)

$\bar{P} . \mathrm{E}\left(\bar{a}_{\overline{n \mid}}\right)=\bar{P} \cdot \bar{a}_{x y z: \overline{n \mid}}=\bar{P} \cdot \int_{0}^{n}{ }_{t} p_{x y z}$ $v^{t} d t$

2. The value of benefit paid by the insurer (Output)

$$
\begin{aligned}
& \text { B. } E\left(V^{T}\right)=\left[\left(Q . \quad\left(\bar{A}_{x y z}: \frac{1}{n \mid}\right)\right)+\right. \\
& \left(\text { Ryz. } n \mid \bar{a}_{y z . n} q_{x}\right) \\
& \left(R x z \cdot{ }_{n \mid} \bar{a}_{x z . n} q_{y}\right) \\
& \left(R x y \cdot n \mid \bar{a}_{x y . n} q_{z}\right. \\
& \left(R x \cdot{ }_{n \mid} \bar{a}_{x . n} q_{y z}\right)+\left(R y \cdot{ }_{n \mid} \bar{a}_{y . n} q_{x z}\right. \\
& )+\left(R z \cdot n \mid \bar{a}_{z . n} q_{x y}\right)+U \cdot\left(\bar{A}_{x y z: n \mid}^{1}\right. \\
& \text { J)]. }
\end{aligned}
$$

3. By using the equivalence principle, the annual premium formulation is obtained

$$
\begin{aligned}
& \bar{P} . \quad \bar{a}_{x y z: \bar{n} \mid}=\left[\left(Q . \quad\left(\bar{A}_{x y z}: \frac{1}{n \mid}\right)\right)+\right. \\
& \left(R y z \cdot n \mid \bar{a}_{y z . n} q_{x}\right) \\
& \left(R x z \cdot n \mid \bar{a}_{x z . n} q_{y}\right) \\
& \left(R x y \cdot n \mid \bar{a}_{x y . n} q_{z} \quad\right) \quad+ \\
& \left(R x \cdot n \mid \bar{a}_{x . n} q_{y z}\right)+\left(R y \cdot{ }_{n \mid} \bar{a}_{y . n} q_{x z}\right. \\
& \text { ) + (Rz.n|} \left.\bar{a}_{z . n} q_{x y}\right)+\left(\text { J. } \left(\bar{A}_{x y z} 1 \overline{n \mid}\right.\right. \\
& \text { )]. } \\
& \bar{P}= \\
& \frac{\left(Q \cdot\left(\bar{A}_{x y z}: \frac{1}{n \mid}\right)\right)+\left(R y z \cdot n \mid \bar{a}_{y z . n} q_{x}\right)}{\bar{a}_{x y z: \bar{n} \mid}}+ \\
& \frac{\left(R x z \cdot n \mid \bar{a}_{x z . n} q_{y}\right)+\left(R x y \cdot n \mid \bar{a}_{x y . n} q_{z}\right)}{\bar{a}_{x y z: \bar{n} \mid}} \\
& +\frac{\left(R x \cdot n \mid \bar{a}_{x . n} q_{y z}\right)+\left(R y \cdot n \mid \bar{a}_{y . n} q_{x z}\right)}{\bar{a}_{x y z: \bar{n} \mid}} \\
& +\frac{\left(R z \cdot n \mid \bar{a}_{z \cdot n} q_{x y}\right)+\left(\mathrm{J} \cdot\left(\bar{A}_{x y z} \frac{1}{n \mid}\right)\right.}{\bar{a}_{x y z: \bar{n} \mid}}
\end{aligned}
$$

Thus, the annual premium formula is denoted by $\bar{P}_{x y z: n}$, and formulated as follows:

$$
\begin{aligned}
& \bar{P}_{x y z: n}=\frac{\left(Q \cdot\left(\bar{A}_{\left.x y z: \frac{1}{n \mid}\right)}\right)+\left(R y z \cdot n \mid \bar{a}_{y z . n} q_{x}\right)\right.}{\bar{a}_{x y z: \bar{n} \mid}}+ \\
& \frac{\left(R x z \cdot n \mid \bar{a}_{x z . n} q_{y}\right)+\left(R x y \cdot n \mid \bar{a}_{x y \cdot n} q_{z}\right)}{\bar{a}_{x y z: \bar{n} \mid}}+ \\
& \frac{\left(R x \cdot n \mid \bar{a}_{x . n} q_{y z}\right)+\left(R y \cdot n \mid \bar{a}_{y \cdot n} q_{x z}\right)}{\bar{a}_{x y z: \bar{n} \mid}}+ \\
& \frac{\left(R z \cdot n \mid \bar{a}_{z . n} q_{x y}\right)+\left(\mathrm{J} \cdot\left(\bar{A}_{x y z: \bar{n} \mid}\right)\right]}{\bar{a}_{x y z: \bar{n} \mid}} .
\end{aligned}
$$

Case examples will be provided to facilitate understanding of the formulation as follows:

1. Insurance starting age Insurance starting age is the age when he registers his self to join insurance. In this case, for two people (husband and wife) and three people (husband and wife and son), the detail of ages is a husband $(x) 50$ years, wife $(y) 45$ years, and son $(z) 15$ years.

2 . Insurance coverage period

The insurance coverage period is the length of time the insurance contract valid. In this case, the insurance coverage period is $n=1-10$ years.

3. Interest Rates

The interest rate that is used in this case is $5 \%$.

4. Benefit

The amount of benefit for two or three people, if all of the participants still alive until the contract end, they are given benefit, namely a sum of 1 rupiah $(Q=1)$. If one of the participant members dies, the premium payment is stopped. The participant who remains alive until the end of the contract will get the benefit of money, that is, the amount of 1 rupiah every year for the rest of his life $(R y=1, R x=$ $1, R z=1, R y z=1, R x z=1, R x y=1$ ). Also, if all of the participants die before the contract ends, the expert inheritance will get a benefit of 1 rupiah $(J=1)$.

Based on the annual premium formulation for two and three people and the case example above is obtained, the 
value of the annual joint-life insurance premium for two and three people can be seen in Table 1 below and can compare the result.

Tabel 1. Annual premiums for two and three people contract

\begin{tabular}{lll}
$\begin{array}{l}\text { Contract } \\
n \text { years }\end{array}$ & $\begin{array}{r}\overline{\boldsymbol{P}}_{\mathbf{5 0 ; 4 5 : n}} \\
\text { (two people) }\end{array}$ & $\begin{array}{c}\overline{\boldsymbol{P}}_{\mathbf{5 0 ; 4 5 ; 1 5 : n}} \\
\text { (three people) }\end{array}$ \\
1 & 1.1228250 & 1.1288090 \\
2 & 0.6293587 & 0.6355765 \\
3 & 0.4695112 & 0.4760903 \\
4 & 0.3929323 & 0.4000484 \\
5 & 0.3495403 & 0.3573477 \\
6 & 0.3226249 & 0.3313351 \\
7 & 0.3050462 & 0.3148549 \\
8 & 0.2932705 & 0.3043200 \\
9 & 0.2852671 & 0.2976445 \\
10 & 0.2797692 & 0.2935317 \\
\hline
\end{tabular}

If it is stated in the graph of the value of the annual joint-life insurance premiums for two and three people, it can be seen in Figure 1.

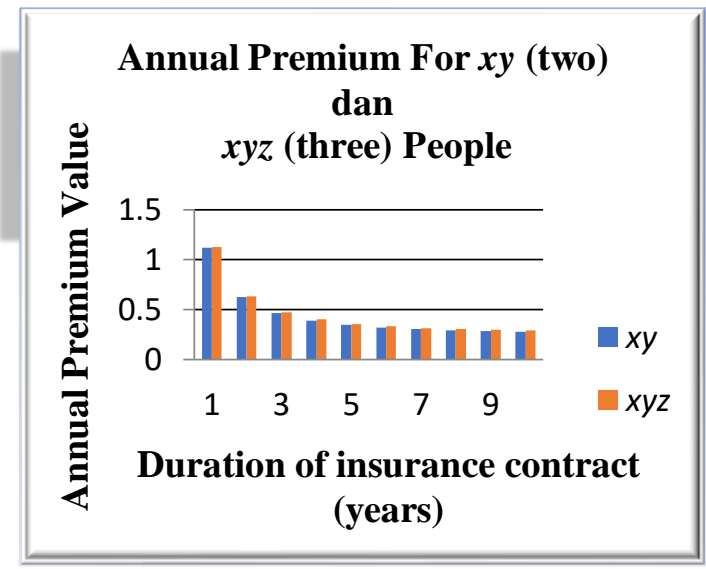

Figure 1. Annual premium for two and three people

Based on Table 1, it can be seen that the amount of the joint-life annual premium with the benefit of each possibility is the duration of the insurance contract strongly influences 1 rupiah, and the number of people is covered. It can be seen that the annual premium for three people is slightly more expensive than for two people, and the shorter the period, so the more significant the annual premium must be paid. For example, a 10-year contract period for two people must pay a premium each year of 0.2797692 . For three people to amount to 0.2935317 with the same benefit amount, if considered, it is more profitable to pay for three people than for two people because of the difference it is the amount of a small annual premium.

Meanwhile, based on Figure 1, with the duration of the insurance contract $(n=$ 1-10 years), it can be seen that the annual premium value decreases every year. For a short term insurance contract, the annual premium is much greater than the long term, and after that, the annual premium is the age of a person. The number of insurance participants, because of the annual premium for three people, is slightly greater than for two people. However, it does not look much different because of the life opportunity that affects it; this can be considered in choosing the type of insurance needed or more profit than a joint-life insurance case for 2 (two) or 3 (three) people.

\section{CONCLUSIONS AND SUGGESTIONS}

Based on the results and discussion in the previous chapter, it can be concluded that the principle of continuous equivalence determines the annual jointlife premium for two and three people. It can be obtained from the formulation of the joint-life insurance annual premium as follows:

1. Formulation of annual joint-life premium for 2 (two) people as follows:

$$
\begin{aligned}
& \bar{P}_{x y: n}=\frac{\left(Q \cdot\left(\bar{A}_{x y}: \frac{1}{n \mid}\right)\right)+(R x \cdot n \mid}{\left.\bar{a}_{x y: n} \bar{a}_{x y} q_{y}\right)}+ \\
& \frac{\left(R y \cdot n \mid \bar{a}_{y \cdot n} q_{x}\right)+\left(J \cdot\left(\bar{A}_{x y} \frac{1}{n !}\right)\right.}{\bar{a}_{x y: \bar{n} \mid}}
\end{aligned}
$$

2. Joint-life annual premium formulation for 3 (three) people as follows:

$$
\bar{P}_{x y z: n}=\frac{\left(Q \cdot\left(\bar{A}_{x y z: \bar{n}}\right)\right)+\left(R y z \cdot n \mid \bar{a}_{y z . n} q_{x}\right)}{\bar{a}_{x y z: \bar{n} \mid}}+
$$


Desimal, 3 (3), 2020 - 269

Stacia Litha Suryani, Rudi Ruswandi, Ahmad Faisol

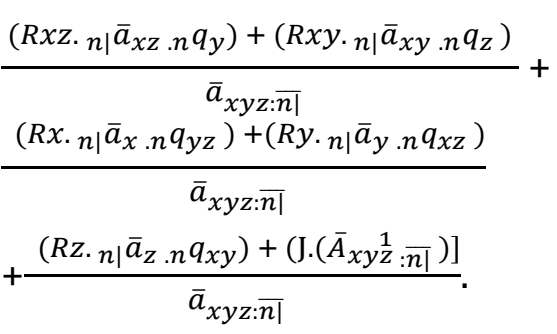

The result of calculations implies that the amount of the annual premium joint-life for two people and three people will affect the table value mortality, annuity, and single premium. Moreover, to determine the annual premium for jointlife life insurance, which causes three people is slightly greater than for two people, this can be a consideration to choose the type of insurance that is desired or which is more profit. It can be concluded that the factors influence the amount of the annual premium are the number of insured, the duration of the insurance contract (period), the age when the policy is signed, the interest rate, life chances, the rate of death, and also the number of benefits to be provided.

\section{REFERENCES}

Bhuana, T. Y., Widana, I. N., \& Harini, L. P. I. (2015). Menentukan premi tahunan untuk tiga orang pada asuransi jiwa hidup gabungan (joint life). E-Jurnal Matematika, 4(4), 195. https://doi.org/10.24843/mtk.2015.v04. i04.p111

Bizaini, B., Dewi Sri, S., \& Yuni, Y. (2016). Asuransi joint life seumur hidup. Epsilon: Jurnal Matematika Murni Dan Terapan, 10(2), 11-17.

Bowers, N. L., Gerber, H. U., Hickman, J. C., Jones, D. A., \& Nesbitt, C. J. (1987). Actuarial mathematics. Transactions of the Faculty of Actuaries. https://doi.org/10.1017/s007136860000 9812

Futami, T. (1993). Matematika asuransi jiwa bagian I. Incorporated Foundation Oriental Life Insurance Cultural Development Center.
Futami, T. (1994). Matematika asuransi jiwa bagian II. Incorporated Foundation Oriental Life Insurance Cultural Development Center.

Ihsan, K., Dodi, D., \& Yanuar, F. (2014). Penentuan premi tahunan pada asuransi joint life dengan menggunakan anuitas reversionary. Jurnal Matematika UNAND, 3(4), 112-120.

Matvejevs, A., \& Matvejevs, A. (2001). Insurance models for joint life and last survivor benefits. Informatica, 12(4), 547-558. https://doi.org/10.3233/INF2001-12405

Sembiring, R. K. (1986). Asuransi I. Karunika Universitas Terbuka. 
Desimal, 3 (3), 2020 - 270

Stacia Litha Suryani, Rudi Ruswandi, Ahmad Faisol 